\title{
IMPACT OF INFRASTRUCTURE DEVELOPMENT JALUR JALAN LINTAS SELATAN (JJLS) ON CHANGES IN LAND USE IN GADINGSARI VILLAGE, SANDEN DISTRICT, BANTUL REGENCY, YOGYAKARTA, INDONESIA
}

\author{
Hendry Edy ${ }^{1)}$, M. Baiquni ${ }^{2)}$, Bambang Triatmodjo ${ }^{3)}$ \\ ${ }^{1}$ Doctoral Student in Environmental Sciences Doctoral Study Program \\ Postgraduate School of Universitas Gadjah Mada \\ ${ }^{2}$ Lecturer in Doctoral Program in Environmental Sciences Postgraduate School of Universitas Gadjah Mada and \\ Lecturer in Regional Development Study Program at the Faculty of Geography, Universitas Gadjah Mada \\ ${ }^{3}$ Lecturer in Doctoral Program in Environmental Sciences \\ Postgraduate School of Universitas Gadjah Mada and \\ Lecturer in Civil Engineering Study Program, Faculty of Engineering, Universitas Gadjah Mada \\ Email: $\underline{{ }^{1} \text { hendry_edy@yahoo.com, }}$ 리 baiquni99@gmail.com, ${ }^{2}$ bambang.tsipil@yahoo.co.id
}

Received 23 March 2019/ Revised 22 July 2019/ Accepted 24 July 2019/ Published 1 August 2019

\begin{abstract}
Infrastructure Development Jalur Jalan Lintas Selatan (JJLS) is a National program that passes through 5 provinces in Java, which is one of the provinces passed through the Special Region of Yogyakarta. One of the villages passed by the JJLS development in the Special Province of Yogyakarta is Gadingsari Village, Sanden District, Bantul Regency. In this study, it will be seen how changes in land use in Gadingsari village before and after JJLS. The purpose of this study was to analyze changes in land use that occurred in Gadingsari Village. The analytical method used is a qualitative descriptive analysis method. Changes in land use were obtained from the Satellite Image Overlay Analysis in the span of time, namely before JJLS was built in 2013 and after JJLS was built in 2017 and strengthened with field surveys and in-depth interviews. From the results of the research, it was found that the land area for settlements in Gadingsari Village before and after the JJLS had changed. Before the existence of JJLS residential area was 78.90 hectare and it expanded to 104.93 hectare after the construction of JJLS, there was an increase of around $32.99 \%$.
\end{abstract}

Key words: Infrastructure, Overlay, JJLS, Land

\section{Introduction}

Java Island belongs to the group of developing regions in its good economic growth, generally located along the northern coast of Java island such as Semarang, Pati, Rembang and Jepara. The opposite condition occurs in the southern part of the island of Java where 
economic growth is slow and there is not much activity and movement of people or goods that occur. This happens because the road infrastructure is on the North Coast where the code is good so the traffic is very heavy. In addition, when viewed from a landscape perspective the North Coast is a lowland with many deltas, while the South Coast coastal area is dominated by steep and thick beaches interspersed with sandy beaches. Geographically, the South Coast region of Java consists of karts mountains and the condition of the region is dry.This condition creates a gap between regions, namely between the northern region and the southern region of Java. The southern part of the island of Java actually has great economic potential including fertile land, mining resources, marine resources, coastal tourism, karst cave tourism, natural and mountain tourism, forest tourism and cultural tourism (historical and cultural heritage). These potentials have not been worked out well due to the limited infrastructure available on the South coast of Java. To overcome these problems, infrastructure development is needed that can support the development of existing potentials.

The availability of infrastructure can have an influence on increasing people's access to resources, thereby increasing access to productivity of resources which ultimately drives economic growth.The construction of roads in an area will open access to the area with other regions so that the flow of vehicles, goods or products can be transported quickly. With the existence of this road, there will be a lot of community efforts in order to fulfill the necessities of life such as opening stalls, restaurants or other businesses which will then move the economy of the local community. If the community along JJLS cannot take advantage of this opportunity, investors will take over to take advantage of this opportunity. One of the infrastructure that is needed in this case is the Road infrastructure. Roads are the driving factor for economic change, regions that have a lot of road access tend to encourage land change in a direction that cannot be reversed (Kubangun et al, 2016). Road is one of the most important infrastructures to support economic activities to overcome the gap in the northern part of Java and the southern part of Java. In this southern part of Java, the government built the Jalur Jalan Lintas Selatan (JJLS). Road is one of the most important infrastructures to support economic activities to overcome the gap in the northern part of Java and the southern part of Java. In this southern part of Java, the government built the Southern Cross Road (JJLS). The construction of the Jalur Jalan Lintas Selatan (JJLS) is one of the government's efforts through the Ministry of Public Works to increase the availability of infrastructure in the southern part of Java. The southern crossroad road was built to reduce the density of transportation on the North Java coast (Pantura) and to spur the development of the region in the South Java region. In addition, the construction of the Jalur Jalan Lintas Selatan (JJLS) is 
also expected to increase access to mobility so that it can encourage economic growth in the areas traveled by JJLS. The Jalur Jalan Lintas Selatan (JJLS) will connect 5 provinces in Java, namely Banten, West Java, Central Java, Yogyakarta and East Java. The implementation of infrastructure development especially roads is expected to provide a variety of positive impacts on the community. The construction of the Southern Cross Roadway is expected to be able to provide various implications for the surrounding communities. In principle, every implementation of development will always be an interaction or conflict of interest between the components of activities and environmental components so that it will cause changes in the environment. The land affected by JJLS construction in Gadingsari Village is the Sultan Ground which belongs to the Sultanate of Yogyakarta. Although its ownership is the Sultanate of Yogyakarta, the Yogyakarta Sultanate gives the opportunity to the community to manage and utilize the land for the benefit of the community. Regulations that must be obeyed by the community are not allowed to build permanent buildings on the Sultan Ground land, so that there are no permanent buildings along JJLS in Gadingsari Village.Road construction will be able to exert influence on the area it passes through, both social, economic and other impacts.

Plans for the construction of the Java Southern Cross Road Network of the Special Province of Yogyakarta are carried out through 3 (three) stages of work, namely short-term, mid-term and long-term programs. In further developments the short-term program (20052007) connected between Congot (Central Java Province boundary) - Srandakan - Poncosari Kretek - Parangtritis - Girijati - Klampok - Planjan - Baron - Duwet (Central Java province boundary) along 130, 305 kilometers by utilizing existing roads through widening the road to $7 \mathrm{~m}$. The long-term program (2008-2025) connects between Congot (Central Java provincial boundary) - Srandakan - Kretek - Parangtritis - Baron-Duwet (Central Java Province boundary) along 117.60 kilometers with a road body of $24 \mathrm{~m} \mathrm{(2 \times 7} \mathrm{m} \mathrm{asphalt} \mathrm{),} \mathrm{make} \mathrm{roads}$ and bridges and tunnels. Especially for tunnel construction, it is still in the discourse so that it is not included in the AMDAL study study.

The target for the construction of the Southern Cross Road in the Special Region of Yogyakarta is divided into 2 programs, namely short-term programs and long-term programs. The short term program is basically to connect the road network across the southern island of Java by utilizing the existing road network. While the long-term program is the construction of a long-term road and bridge network not entirely through network routes in short-term programs due to several technical matters and other considerations. The route used in the long-term program in the Bantul Regency area has a slight shift in the route with a road 
length of 6.82 kilometers (dirt road) connecting through the Srandakan III Bridge, the total length for the segment congot-srandakan is 25.65 kilometers. The route from SrandakanPrangtritis passes an existing road network with a segment length of 23.40 kilometers. The route from Srandakan - Parangtritis passes an existing road network with a segment length of 23.40 kilometers. Parangtritis route - Baron is still awaiting the results of further studies to determine the final route (there is a separate study of the possibility of making tunnels) Baron Route - Duwet uses an existing route in accordance with the route developed for short-term programs. The length of this route is 41.09 kilometers. One of the villages passed by the construction of the Jalur Jalan Lintas Selatan (JJLS) is Gadingsari Village, located in Sanden District, Bantul Regency, Special Region of Yogyakarta.

The construction of the road in Gadingsari village began in 2013. Road construction was carried out by widening the existing roadway. After the completion of the construction of the Jalur Jalan Lintas Selatan (JJLS) in Gadingsari Village, land use changes occurred, especially the increase in land used for settlements. The purpose of this study is to find out changes in land use that occurred in Gadingsari Village before the construction of the Jalur Jalan Lintas Selatan (JJLS) in 2013 and after the existence of the Jalur Jalan Lintas Selatan (JJLS) in 2017. The construction of JJLS is expected to support economic activities and will tackling the gap in the northern part of Java and the southern part of Java. In this study we will look at the impact of JJLS development on changes in land use. Most of the land before the construction of JJLS was land in the form of moor, gardens or rainfed rice fields which would be transformed into residential land.

\section{The Methods}

Gadingsari Village is located in Sanden Subdistrict, Bantul Regency with an area of 811.74 hectares with regional boundaries as follows:

North Side: Caturharjo Village, Pandak District

South side: Indonesian Ocean

West side: Poncosari Village, Srandakan District

East: Murtigading and Gadingharjo Village, Sanden District

The research location is Gadingsari Village, Sanden District, Bantul Regency can be seen in Figure 1. 


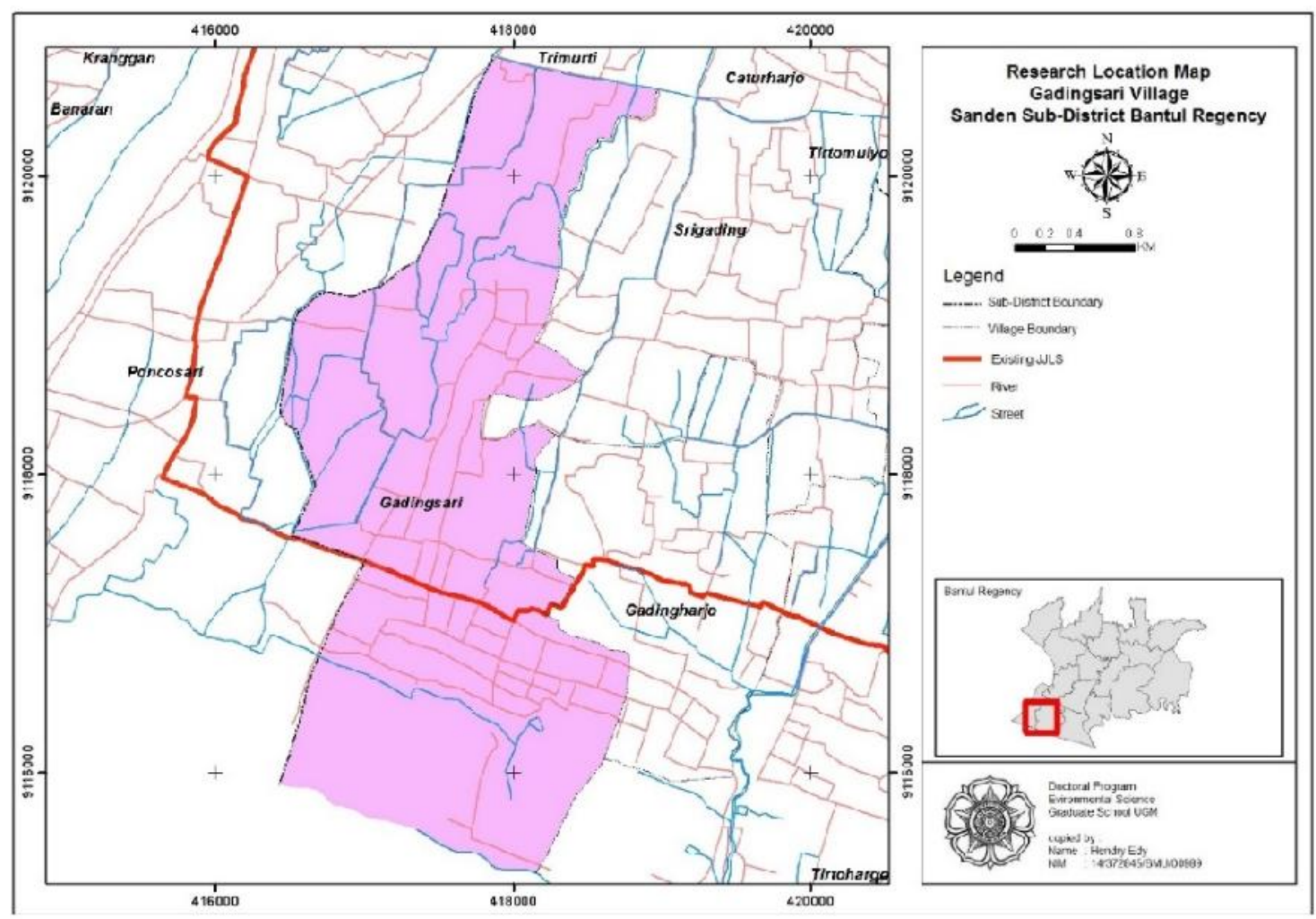

Figure 1. Map of Research Location in Gadingsari Village

In this study the tool used is a computer (hardware) that is used to digitize maps, software (GIS software) to process spatial data: ArcGis 10.2 and Google Earth take digital images and GPS (Global Positioning System) used in fieldwork to shows the position so that it matches the predetermined point. The material used in this study is the map of Sindutan village administration, maps of Sindutan village land use in 2013 and 2017 sourced from existing images on google earth, secondary data of Sindutan village monograph and other data related to research. Data collection techniques in this study are documentation, image interpretation, observation and in-depth interviews. As the primary data in this study are the images obtained from Google Earth Sindutan Village, Sanden Subdistrict, Bantul Regency in 2013 and 2017. The primary data in this study is satellite imagery for the Sindutan village area. Furthermore, for secondary data can be obtained directly through the agency government agency at the research location. Imagery can be interpreted as a visible picture of an object being observed, as a result of coverage or recording of a monitoring device / sensor, both optical, electro optical, optical-mechanical, or electromagnetic (Kusumaningrat et al, 2017). Image requires a process of interpretation or interpretation in advance in its use. In this research, image interpretation is done using the Arcgis 10.2 program. in the form of visual interpretation, by interpreting or digitizing images to separate certain objects to produce a 
map of land use change. Based on image interpretation, it can be seen land use, and area of use in each year of shooting, so that from this interpretation results obtained two tentative maps of land use (in 2013 and 2017). The results of this interpretation are tentative and incomplete maps. This tentative map so that it becomes a complete map and has a high level of trust, it is necessary to do a field check (observation). Observation is a way to collect research data through observation, recording, and visiting agencies to get the data needed. From the observation activities data can be obtained that may not be obtained from the image so that the map of the interpretation results can be corrected according to the latest data and can become the actual map. During this observation, in-depth interviews were also conducted. The purpose of the interview was to look at land use in the research area when conducting field checks. Is the condition appropriate or not in accordance with the appearance shown in the image. Interviews were conducted with residents around the land use and knowing the history of the land use.

The data analysis technique in this study was carried out by analysis of the Geographic Information System. Analysis of changes in land use by utilizing temporal spatial data is very useful, especially to find out the locations where changes in land use occur (Nuraeni, et al, 2017). In this study data was obtained from the results of image interpretation analyzed, namely the 2013 land use map and 2017, then the data was analyzed. The analysis at this stage is the reinterpretation (reinterpretation) of the map done after testing the accuracy and observation. From the reinterpretation process, an overlayed land use change map will be produced (data for 2013 and 2017). Analysis of changes in land use, area of each land use, extent of change, with analysis of geographic information systems. Each of the different land use maps is stacked with the Overlay technique, so that changes in type, area, and area of land change can be identified to produce information in the form of land use change maps in Sindutan Village, Sanden District, Bantul Regency. After doing the Geographic Information System (GIS) analysis technique with the Overlay technique then qualitative descriptive analysis techniques were carried out. Descriptive analysis is used to explain the findings in the field. The findings of the study included extensive changes in land use and types of land use.

\section{Results and Discussion}

The land use map is taken from the imagery that is on Google Earth Temporal, then a visual interpretation of each temporal is carried out with the Arcgis 10.2 program. From the 
results of the land use map analysis in 2013 which can be seen on the land use map in Gadingsari village in figure 2 and the area for each land use in Table 1 . The lake area is 0.50 hectares, bushes of 3.39 hectares, for gardens covering 281.73 acres of settlement covering 78.9 hectares, irrigated rice fields covering 226.09 hectares, moorlands covering 94.59 hectares, land sand covering an area of 78.72 hectares and grass area of 6.05 hectares.

Table 1. Table of 2013 Land Use Maps

\begin{tabular}{clr}
\hline No & \multicolumn{1}{c}{ Land Use } & Large (Hectares) \\
\hline 1. & Lake & 0,50 \\
2. & Bushes & 3,39 \\
3. & Garden & 281,73 \\
4. & Settlement & 78,90 \\
5. & Irrigated rice fields & 226,09 \\
6. & Moorings & 94,59 \\
7. & Land Sand & 78,72 \\
8 & Grasses & 6,05 \\
\hline
\end{tabular}

Source: Interpretation of Google Earth Images 2013

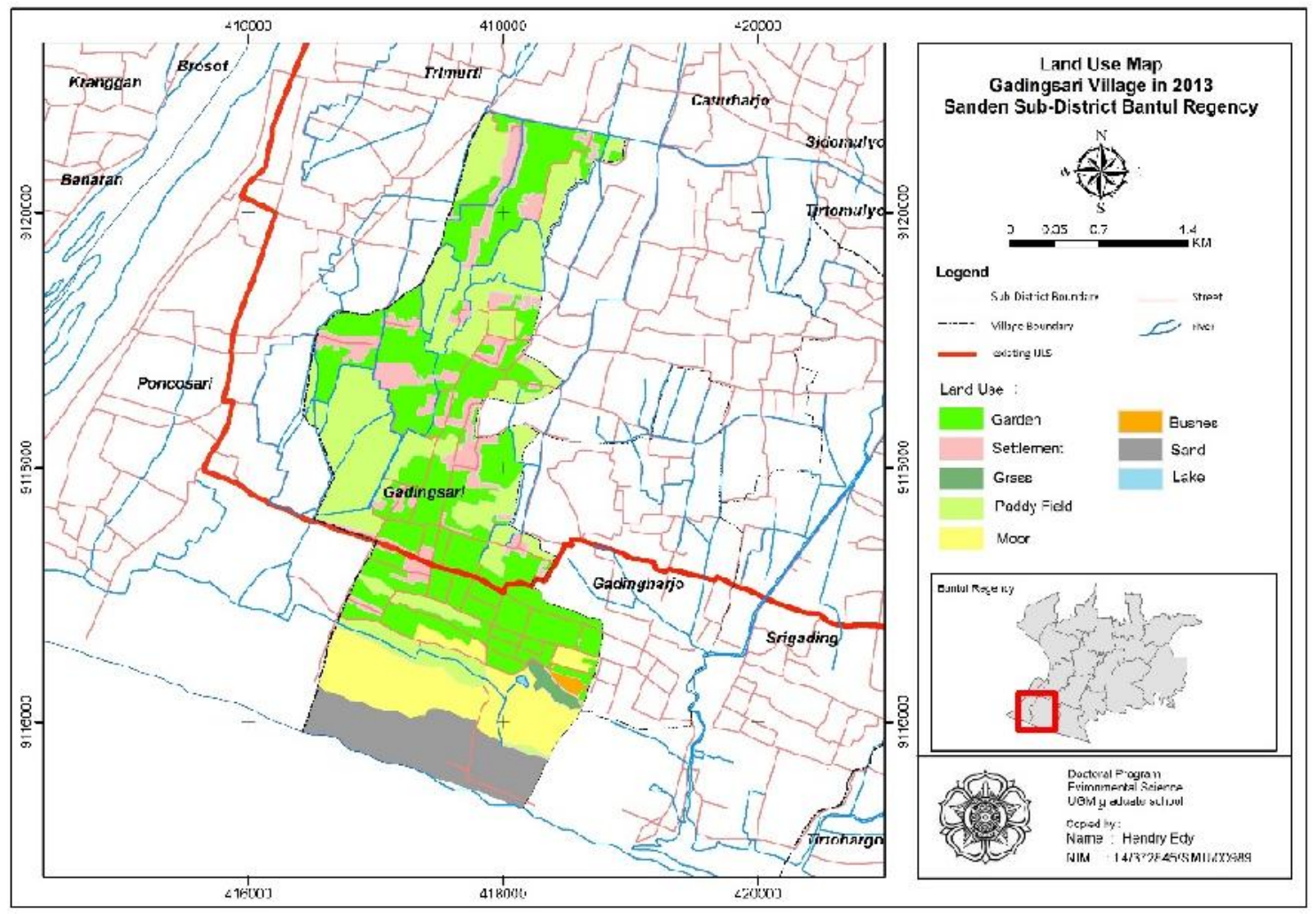

Figure 2. Map of Land Use in Gadingsari Village in 2013

Whereas the land use of Gadingsari village in 2017 can be seen on the land use map in figure 3 and the area of each land use can be seen in table 2. Lake area is 0.50 hectares, bushes are 3.39 hectares, for gardens covering 259.95 hectares, settlement 104.93 hectares, irrigated rice 
fields covering 226.09 hectares, moorlands covering 94.59 hectares, land sand covering an area of 75.74 hectares and grasses covering an area of 6.05 hectares.

Table 2. Table of 2017 Land Use Maps

\begin{tabular}{clr}
\hline No & \multicolumn{1}{c}{ Land Use } & Luas ( Hectares ) \\
\hline 1. & Lake & 0,50 \\
2. & Bushes & 3,39 \\
3. & Garden & 259,95 \\
4. & Settlement & 104,93 \\
5. & Irrigated rice fields & 226,09 \\
6. & Moorings & 93,32 \\
7. & Land Sand & 75,74 \\
8. & Grasses & 6,05 \\
\hline
\end{tabular}

Source: Interpretation of Google Earth Images 2017

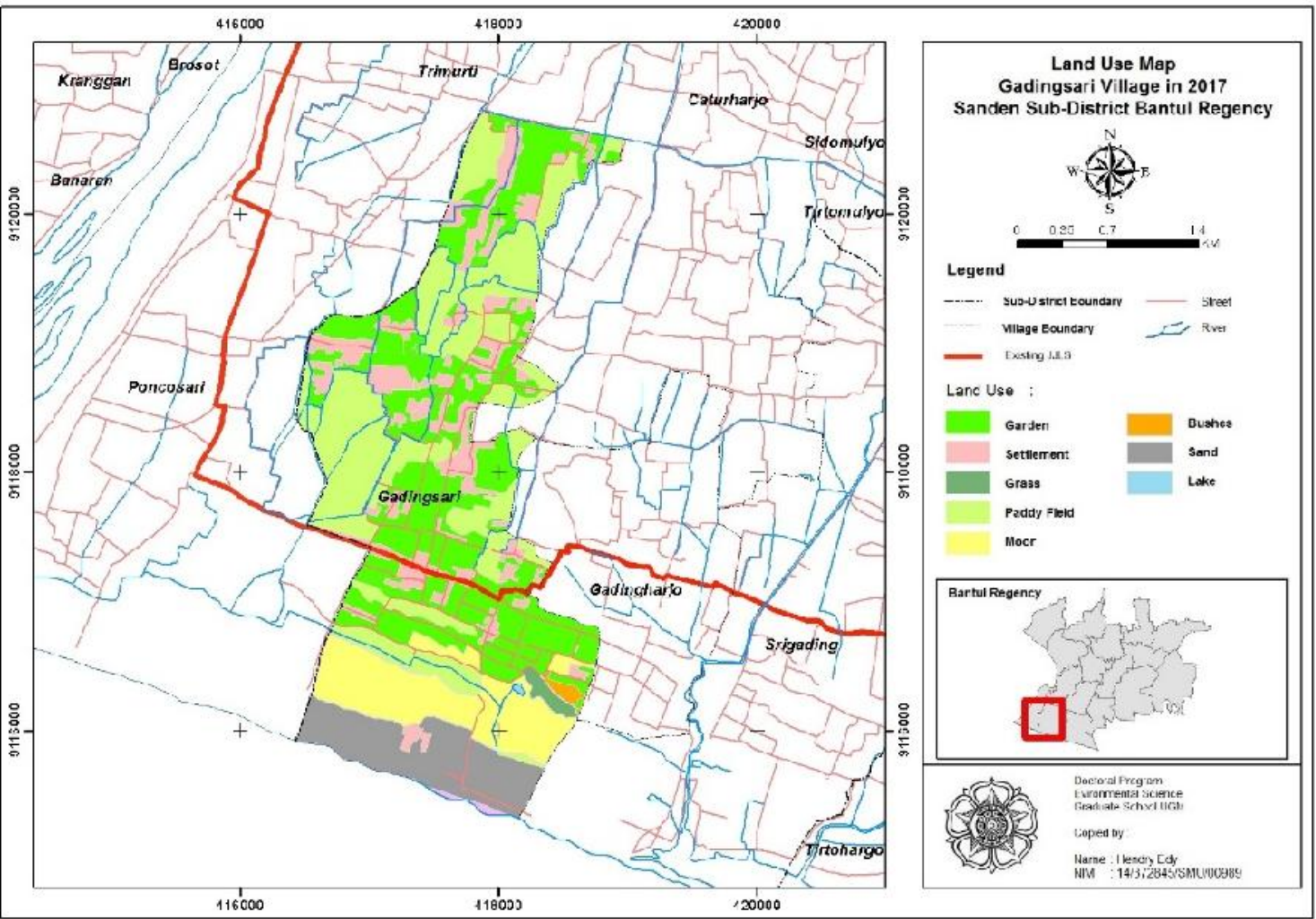

Figure 3. Map of Gadingsari Village Land Use in 2017

Changes in land use in 2013 to 2017 can be seen in figure 4. The extent of land use change that occurred from 2013 before the JJLS and in 2017 after the JJLS can be seen in table 3. 
The change in garden land into a settlement of 21.78 hectares, changes the dry land is a settlement of 1.27 hectares while the land sand is a residential area of 2.98 hectares.

Table 3. Table of Changes in Land Use in 2013 to 2017

\begin{tabular}{llrrrr}
\hline \multirow{2}{*}{ No } & \multirow{2}{*}{ Land Use } & \multicolumn{2}{c}{ Large (Hectares) } & \multicolumn{2}{c}{ Change (Hectares ) } \\
\cline { 3 - 6 } & & \multicolumn{1}{c}{2013} & \multicolumn{1}{c}{2017} & Increase & Reduced \\
\hline 1. & Lake & 0,50 & 0,50 & & \\
2. & Bushes & 3,39 & 3,39 & & \\
3. & Garden & 281,73 & 259,95 & & 21,78 \\
4. & Settlement & 78,90 & 104,93 & 26,03 & \\
5. & Irrigated rice fields & 226,09 & 226,09 & & \\
6. & Moorings & 94,59 & 93,32 & & 1,27 \\
7. & Land Sand & 78,72 & 75,74 & & 2,98 \\
8. & Grasses & 6,05 & 6,05 & & \\
\hline
\end{tabular}

Source: Interpretation of Google Earth Images 2013-2017

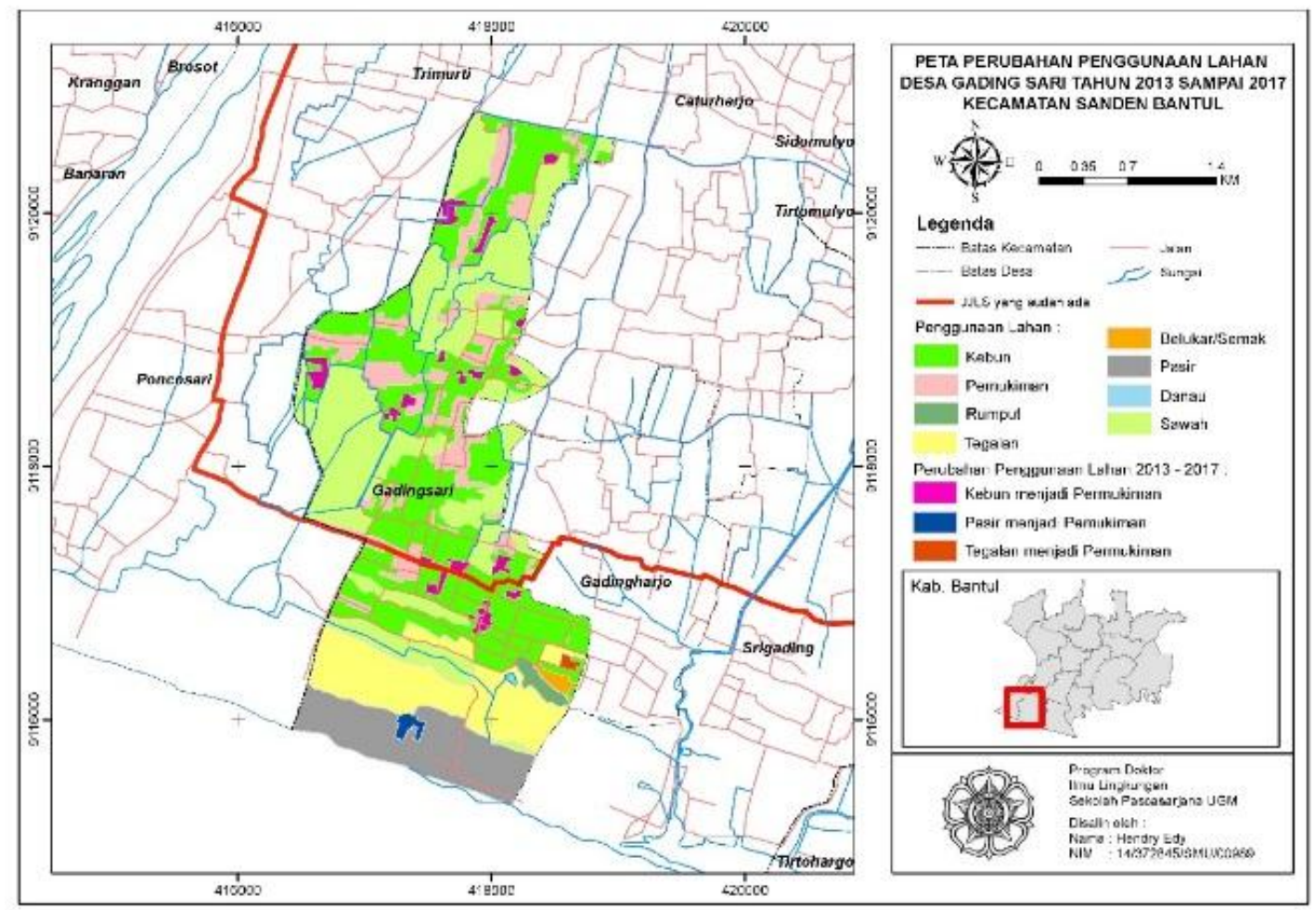

Figure 4. Map of Changes in Land Use of Gadingsari Village from 2013 to 2017

In the study of land use change in Gadingsari Village, land use changes occurred before the South Cross Road (JJLS) occurred in 2013 and after the existence of JJLS in 2017. Changes in land use that occurred on agricultural land turned into residential land and land 
changes. the road along the JJLS Gadingsari Village found many flower gardens that were deliberately made by the surrounding community. These botanical gardens are tourist attractions for tourists, tourists can take pictures in the park with payment of retribution, so that this retribution can provide information for people who manage the land around JJLS Gadingsari Village.

There are several other studies related to changes in land use. Fadilla Restu et al, 2018 agreed on the Conformity Analysis of Changes in Land Use to Spatial / Regional Plans in the Districts of Penjaringan, North Jakarta Administration, Using Geographic Information Systems. This study discusses the suitability of the plan with the existing conditions in the field with mapping. This study focuses more on 2013 land use suitability for the Jakarta Spatial Planning (RTRW) in 2030.

Ahardi M. Ardhi et al .'s research in 2015 on the Effect of Changes in Land Use on Changes in Land Value Zones in Gayamsari Sub-District, Semarang City in 2004 and 2014. The results of this study indicate the total area of land use change in Gayamsari Subdistrict in 2004 to 2014 was 106 ha. The biggest change in land use occurs in the use of dry land into settlements with an area of 24 ha. Beatus M. Laka et al., 2017 examined the Changes in Land Use in Sirimau District, Ambon City. Based on the results of the study it was concluded that the change in the area of land use in Sirimau District, Ambon City, in the last 10 years was very large for settlements of $1036.1 \mathrm{Ha}$ from the previous year amounting to 966.9 Ha.Another researcher who examined the related changes in land use was Sadewo M Nur et al, 2018 which examined Simulation of Changes in Land Use due to Cellular Automata-based Kendal Industrial Estate (KIK) Development.

Based on the results of the research that has been done, it can be concluded that the cellular automata model is able to predict land use in 2031 in East Kendal with the influence of KIK development with a model accuracy rate of 95.68\%. Murdaningsih, et al., 2017 conducted a study on spatial analysis of changes in agricultural land use to support food independence in Indramayu Regency. The results showed that land use in Indramayu in 1994 was dominated by paddy fields with an area of 133,716 ha (65\%), farms covering an area of 18,780 ha (9\%) and settlements covering an area of 16,627 ha (8\%). In 2015, wetland area fell to 132,097 ha $(64 \%)$ and settlements increased to 18,625 ha $(9 \%)$. Changes in paddy fields will affect food availability.Nuraeni, R., et al., 2017 examined the Analysis of Changes in Land Use and Regional Land Use Directives in Bandung Regency. The results showed that land use in Bandung Regency experienced a change with the pattern of dominant change, namely forest into built land, plantations into built land, wetland agricultural plants (TPLB) 
into built-up land, TPLB became dry land agricultural crops (TPLK) and TPLK became builtup land . The existing condition of land use in 2012 shows a mismatch with a space allocation of 54 ha.

Kusumaningrat M., et al 2017 examined the Analysis of Changes in Land Use and Utilization of the 2009 and 2017 Regional Spatial Planning (Case Study: Boyolali Regency). From the results of the study there was a change in land use to get results, economic activities decreased by 1275.9 hectares, social activities increased by 91.41 hectares, utilization of dwellings increased by 1363.16 hectares and classification of no use decreased by 210.61 . Changes in land suitability over a period of 8 years increased by 1291.19 hectares or $1.18 \%$. Another researcher who examined land use change was Kubangun, et al. 2016 who conducted a study on the Change / Land Use Change Model for Critical Land Identification in Bogor Regency, Cianjur Regency and Sukabumi Regency.The results of this study indicate that land classified as critical includes sloping land with converted land use / land use. The main factor causing land conversion is the high demand for food, clothing, and shelter, due to increasing population density.

\section{Conclusion}

From the results of the research conducted by the authors it can be concluded that the construction of the Southern Cross Road (JJLS) which passes through Gadingsari Village, Sanden District, Bantul Regency has an impact on land use in Gadingsari village. Changes in land use occurred before the construction of JJLS in 2013 and after the construction of JJLS in 2017. Prior to the JJLS settlement area of 78.90 hectares and expanded to 104.93 hectares after the construction of JJLS, there was an expansion of around 32.99\%. which initially amounted to 94.59 hectares to 93.32 hectares, decreased by about $1.34 \%$, the area experienced a reduction in area from which initially had an area of 281.73 hectares to 259.95 hectares, an area of $7.73 \%$ decreased and land area reduced by 78.72 hectares to 75.74 hectares reduced around $3.78 \%$.

\section{References}

Ahardi Muhammad A., Sawitri S. \& Abdi S. (2015). Pengaruh Perubahan Penggunaan Lahan Terhadap Perubahan Zona Nilai Tanah di Kecamatan Gayamsari Kota Semarang Tahun 2004 dan 2014Jurnal Geodesi Undip, 4(4), 316-324. 
Beatus M. Laka, Uca Sideng \& Amal (2017). Perubahan Penggunaan Lahan di Kecamatan Sirimau Kota Ambon .Jurnal Geocelebes, 1(2), 43-52.

Fadilla Restu, Sudarsono B. \& Bashit N.(2018). Analisis Kesesuaian Perubahan Penggunaan Lahan Terhadap Rencana Tata Ruang/wilayah di Kecamatan Penjaringan kota Administratif Jakarta Utara Menggunakan Sistem informasi Geografis. Jurnal Geodesi Undip, 7(1), 109-119.

Kubangun Siti Hadjar, Haridjaja O.\&Gandasasmita K. (2016). Model Perubahan Penutupan / Penggunaan Lahan untuk Identifikasi Lahan Kritis di Kabupaten Bogor , Kabupaten Cianjur dan Kabupaten Sukabumi Majalah Ilmiah Globe, 18(1), 21-32.

Kusumaningrat Merpati D., Sawitri Subiyanto\&Yuwono B. D. (2017) Analisis Perubahan Penggunaan dan Pemanfaatan Lahan Terhadap Rencana Tata Ruang Wilayah tahun 2009 dan 2017 (Studi kasus : Kabupaten Boyolali). Jurnal Geodesi Undip, 3, 28-43.

Murdaningsih, Widiatmaka, Munibah, L. \& Ambarwulan, W. (2017). Analisis Spasial Perubahan Penggunaan Lahan Pertanian Di Kabupaten Indramayu. Majalah Ilmiah Globe, 19(2), 175-184.

Nuraeni, R., Sitorus, S.R P. \& Panuju, D.R. (2017). Analisis Perubahan Penggunaan Lahan dan Arahan Penggunaan Lahan Wilayah di Kabupaten Bandung. Buletin Tanah Dan Lahan, 1(1), 79-85.

Sadewo M Nur, Imam B. (2018). Simulasi Perubahan Penggunaan Lahan Akibat Pembangunan Kawasan Industri Kendal (KIK) Berbasis Cellular Automata. Majalah Geografi Indonesia, 32(2), 115-122. https://doi.org/10.22146/mgi.33755

Wahyuni, S., Guchi, H., \& Hidayat, B. (2014). Analisis Perubahan Penggunaan Lahan dan Penutupan Lahan Tahun 2003 dan 2013 di Kabupaten Dairi. Jurnal Online Agroekoteknologi, 2, 1310-1315.

Wahyunto, M.Z. Abidin, A. Priyono \&Sunaryo (2001). Studi Perubahan Penggunaan Lahan di Sub DAS Citarik, Jawa Barat dan DAS Kaligarang, Jawa Tengah. In Prosiding Seminar Nasional Multifungsi Lahan Sawah (pp. 39-40). 